\title{
Pemetaan Geotapak Pulau Ular di Langkawi, Malaysia
}

(Geosite Mapping of Pulau Ular in Langkawi, Malaysia)

\section{Kamal Roslan Mohamed*, Tanot Unjah, Che Aziz Ali \& Mohamad Hanif Kamal Roslan}

\section{ABSTRAK}

Pemetaan Geotapak untuk Pulau Ular telah dijalankan menggunakan kaedah penderiaan jauh yang melibatkan data peta topografi, gambar udara, imej satelit serta gambar yang diambil menggunakan dron. Analisis penderiaan jauh ini menghasilkan peta geomorfologi. Langkah seterusnya adalah melakukan kerja lapangan yang akhirnya menghasilkan satu peta geologi. Cerapan lapangan telah dapat mengenal pasti fitur geologi dan landskap yang penting dan menarik, dan sebanyak 10 lokaliti atau tapak telah dikenal pasti mempunyai fitur geologi atau landskap yang penting kepada pemahaman sejarah pembentukan pulau ini, antaranya kepelbagaian jenis batuan, fosil, struktur sedimen, struktur tektonik dan fitur hakisan. Berdasarkan semua maklumat yang diperoleh ini, peta geotapak Pulau Ular telah dibangunkan dan boleh digunakan dalam membuat perancangan pemuliharaan dan pembangunan geopelancongan.

Kata kunci: Kepelbagaian geologi; pemetaan geotapak

\section{ABSTRACT}

Geosite mapping of Pulau Ular was conducted using remote sensing which includes data from topographic maps, aerial photograph, and satellite image as well as a photographs made by a drone. A geomorphological map was generated by remote sensing analysis. The next step was field work/observation to produce a geological map. Field observation identified 10 sites and localities with important and significant geological and landscape features for an understanding of the geological formation of this island such as rock, fossil, sedimentary structure, tectonic structure and erosion feature. Using all this information a geosite map of Pulau Ular was constructed and can be used in conservation planning and geotourism development.

Keywords: Geodiversity; geosite mapping

\section{PENGENALAN}

Pemetaan geotapak dalam pemuliharaan sumber warisan geologi dikatakan sebagai perkara asas untuk pengurusan guna tanah, perlindungan sumber tabii yang berkesan melalui persempadanan jelas, pemindahan dan perkongsian maklumat yang lebih mudah serta senang difahami atau sebagai alat asas bagi pengurusan dan perancangan sekitaran (Fuertes-Gutiérrez \& Fernández-Martínez 2012) yang diaplikasikan melalui peta bencana kawasan pemuliharaan (Ovreiu et. al. 2019; Wang et al. 2019).

Berdasarkan kajian terdahulu, peta yang dihasilkan dinamakan sebagai 'geotourist map' yang dijelaskan oleh geo sebagai maklumat geosains (geografi, geologi atau geomorfologi) manakala tourist sebagai pelancong atau aspek rekreasi yang tujuan pengunaan peta berkenaan (Regolini-Bissig 2010; Regolini-Bissig \& Reynard 2010). Peta lain yang berkaitan geotapak termasuk peta analisis dan pertindihan kepelbagaian geologi (Silva et al. 2014) dan peta pengurusan bencana di kawasan pemuliharaan (Ovreiu et al. 2019; Wang et al. 2019). Kebanyakan peta awal yang dibangunkan oleh penyelidik ini memenuhi keperluan bukan pakar, memberikan komunikasi maklumat geosains dan integrasi maklumat tentang kemudahan dan perkhidmatan pelancongan. Hanya beberapa peta geotapak yang dibangunkan di United Kingdom lebih bersifat menjawab keperluan pemuliharaan dan perancangan namun masih mengekalkan pendekatan pemetaan geologi asas mengikut kepelbagaiaan geologi yang dikenal pasti (Prosser et al. 2006). Begitu juga dengan peta tindanan kepelbagaian geologi yang dibangunkan untuk tapak di Brazil (Silva et al. 2014) dan pengurusan bencana di kawasan pemuliharaan yang sangat mengkhusus kepada pemantauan (Ovreiu et al. 2019; Wang et al. 2019).

Pemetaan geotapak oleh Regolini-Bissig (2010) dan dikemaskan oleh Fuertes-Gutiérrez and FernándezMartínez (2012) menghasilkan dua peta utama iaitu: Penjelasan peta dengan perwakilan geotapak yang memberikan gambaran keseluruhan warisan di sekitar kawasan berkenaan; dan peta aplikasi yang menggunakan peta asas memasukkan risiko hakisan geotapak dan potensi pengunaan geotapak yang bersesuaian.

Pemetaan geotapak di Langkawi dalam konteks pemuliharaan sumber warisan geologi bertujuan untuk menyediakan dokumen perincian sesebuah tapak bernilai warisan, perlindungan tapak melalui persempadanan yang jelas dan menyediakan makluman yang senang difahami oleh pelbagai pihak berkepentingan serta boleh diguna pakai dalam pengurusan dan perancangan guna tanah yang 
lebih berkesan (Tanot Unjah et al. 2012). Peta ini khusus untuk kegunaan pakar bidang geosains sebagai sebahagian daripada pencirian geotapak dan persempadanan kawasan untuk perancangan pemuliharaan.

\section{GEOLOGI FORMASI SINGA}

Kawasan barat laut Semenanjung Malaysia, terutamanya Kepulauan Langkawi merupakan kawasan penting untuk kajian geologi Semenanjung Malaysia. Ini disebabkan kawasan ini mengandungi jujukan batuan Paleozoik yang paling lengkap (Jones 1981; Koopmans 1965), bermula dengan batuan yang paling tua (Kambrian) yang pernah ditemui di Malaysia, hinggalah kepada batuan yang muda iaitu berusia Trias (Rajah 1). Singkapan yang ada di kawasan ini juga dianggap antara yang terbaik, terutamanya singkapan di tepi pantai berbatu, kuari, perbukitan (terutamanya batu kapur) dan juga singkapan jalan raya.

Kepelbagaian batuan dan landskap yang menarik di Langkawi telah menjadikan kepulauan ini sebagai tempat tumpuan pelancongan berasaskan sumber tabii, kerana Langkawi mempunyai banyak geotapak yang penting (daripada segi nilai sainstifik) dan menarik untuk dilawati. Kertas kerja ini akan menjelaskan bagaimana pemetaan geotapak dilakukan dan cadangan geotrail untuk Pulau
Ular, iaitu salah satu geotapak utama di Langkawi. Pulau Ular terletak di kawasan barat daya Pulau Langkawi, dan terdiri daripada beberapa buah bukit kecil yang dipisahkan oleh satu dataran yang hampir rata. Keseluruhan Pulau Ulat terdiri daripada batuan Formasi Singa (Ahmad Jantan 1973; Mohamad Hanif et al. 2018, 2017, 2016).

Formasi Singa didominasi oleh batu lumpur, batu lodak dan batu pasir. Kadangkala terdapat lapisan batu lumpur dan batu pasir yang masif. Antara struktur sedimen paling lazim ditemui termasuklah perlapisan dan laminasi silang, kesan riak, kesan alur, struktur beban, struktur nyala, dan struktur nendatan (Mohamad Hanif et al. 2016). Seringkali juga ditemui batu pasir dan batu lodak yang mengisi lubang korekan atau alur rayapan sebagai fosil surih menegak dan mendatar. Pada bahagian tertentu dalam formasi ini ditemui lapisan batu lumpur atau batu lodak berpebel pelbagai saiz, bentuk dan asalan. Pebel ini telah ditafsirkan sebagal pebel yang diangkut oleh air batu apung atau lebih dikenali sebagai tilloid dalam sekitaran samudera (Stauffer \& Lee 1986; Stauffer \& Mantajit 1981). Formasi Singa dikatakan menindih Formasi Setul secara tidak selaras dan formasi ini kaya dengan fosil Perm Awal (Leonova et al. 1999; Mohd Shafeea 2003, 1997a, 1997b, 1996; Shi et al. 1997). Di Pulau Rebak terdapat Ahli Rebak yang berusia Karbon (Gobbett 1972; Hamada 1969, 1968;

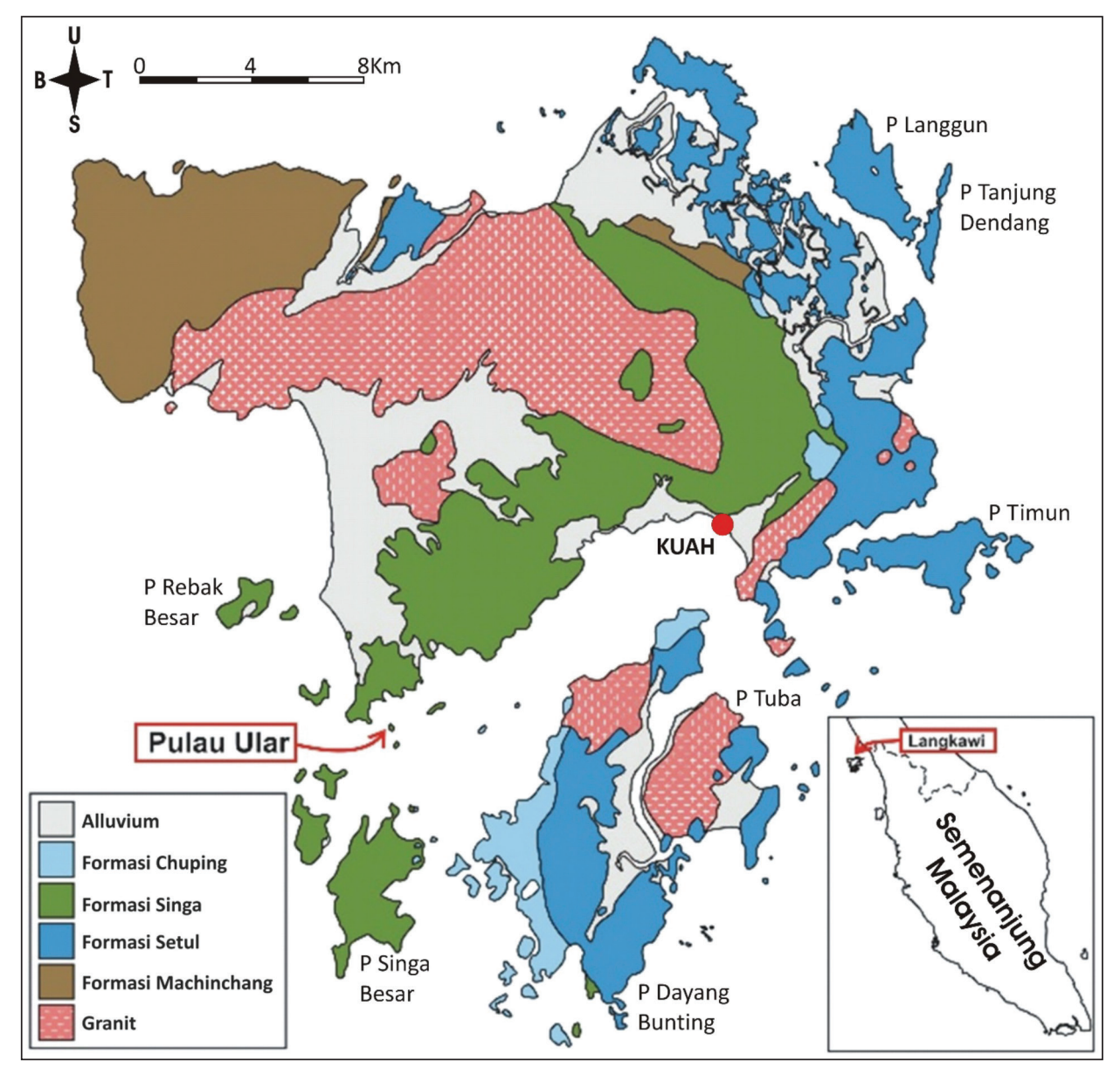

RAJAH 1. Peta geologi Pulau Langkawi dan kedudukan Pulau Ular. Peta diubah suai daripada Jones 1981 
Kobayashi \& Hamada 1973; Sarkar 1972; Yancey 1972) dan disebabkan perbezaan usia yang besar, ahli ini telah dikeluarkan daripada Formasi Singa oleh Mat Niza et al. (2014). Kajian terkini oleh Mohamad Hanif et al. (2018) telah membahagikan formasi ini kepada Ahli Kentut (paling bawah), Ahli Alar, Ahli Selang dan Ahli Lembong (paling atas).

\section{TEKNIK PEMETAAN GEOTAPAK PULAU ULAR}

Pemetaan geotapak merupakan lanjutan kepada pemetaan geologi, dengan kata lain, peta geologi merupakan peta asas atau peta dasar kepada peta geotapak. Memandangkan Pulau Ular mempunyai saiz yang kecil iaitu kurang daripada 400 meter panjang dan lebar sekitar 100 meter, maka bentuk dan garis pantai pulau ini tidak kelihatan dalam peta topografi yang berskala 1:50,000. Untuk mengatasi masalah ini, gambar udara (daripada Jabatan Pemetaan Negara) dan imej satelit daripada google earth digunakan untuk mendapatkan garis pantai dengan tepat, dan dibantu oleh gambar daripada udara (menggunakan dron). Selain kajian kepustakawan, Jadual 1 menunjukkan beberapa langkah/teknik yang digunakan dan maklumat yang diperoleh untuk setiap teknik yang digunakan.

Gerak kerja dalam Jadual 1 ini boleh dibahagikan kepada tiga bahagian; iaitu penderiaan jauh, kerja lapangan dan analisis geotapak.

\section{PENDERIAAN JAUH}

Penderiaan Jauh melibatkan analisis peta topografi, gambar udara, imej satelit serta gambar yang diambil menggunakan dron. Peta dasar dibina menggunakan imej satelit dan gambar dron dengan garis pantai dapat ditanda dengan tepat, pasir, batuan dan hutan dapat dibezakan serta beberapa struktur geologi seperti lineamen dapat ditanda. Kemudian, dalam imej yang ada ini juga dapat ditandakan dengan mudah dan tepat kedudukan daratan rendah dan kawasan berbukit serta fitur takik laut. Daripada kajian ini, satu peta dasar dan peta geomorfologi (Rajah 2) telah dihasilkan.

\section{KERJA LAPANGAN}

Kajian ini melibatkan lawatan lapangan seperti mana ahli geologi membuat peta geologi. Peta dasar dan peta geomorfologi digunakan sebagai asas untuk melakukan kerja lapangan ini. Daripada kerja lapangan yang dilakukan, didapati batuan yang membentuk Pulau Ular adalah terdiri daripada batuan Formasi Singa, iaitu mewakili unit Ahli Ular dan Ahli Selang.

Ahli Ular Ahli Ular terdiri daripada jujukan batuan syal nipis yang berselang lapis dengan batuan lodak dan pasir halus yang nipis. Secara umumnya, Ahli Ular di Pulau Ular boleh dibahagikan kepada tiga unit:

JADUAL 1. Teknik pemetaan yang digunakan untuk menghasilkan peta geotapak Pulau Ular

\begin{tabular}{|c|c|c|c|}
\hline $\begin{array}{c}\text { Langkah / } \\
\text { Teknik }\end{array}$ & Data yang digunakan & Maklumat yang diperoleh & Keterangan \\
\hline 1 & $\begin{array}{l}\text { Peta Topografi skala } \\
1: 50,000\end{array}$ & $\begin{array}{l}\text { Kedudukan kawasan (latitut \& } \\
\text { longitut) }\end{array}$ & $\begin{array}{l}\text { Garis pantai tidak dapat disurih kerana pulau terlalu kecil } \\
\text { untuk peta skala ini }\end{array}$ \\
\hline 2 & Gambar udara & $\begin{array}{l}\text { Boleh bezakan kawasan } \\
\text { berpasir, berbatu dan kawasan } \\
\text { ditutupi tumbuhan }\end{array}$ & $\begin{array}{l}\text { Imej pulau masik kecil dan tidak sesuai untuk surih } \\
\text { garis pantai }\end{array}$ \\
\hline 3 & $\begin{array}{l}\text { Imej satelit daripada } \\
\text { google earth }\end{array}$ & $\begin{array}{l}\text { Garis pantai; kawasan berpasir, } \\
\text { berbatu dan yang ditumbuhi } \\
\text { pokok; struktur lineamen/sesar/ } \\
\text { kekar }\end{array}$ & $\begin{array}{l}\text { Garis pantai jelas kelihatan dan dengan mudah boleh } \\
\text { disurih. Struktur lineamen sangat mudah dikesan dan } \\
\text { ditanda di atas peta }\end{array}$ \\
\hline 4 & Imej daripada dron & $\begin{array}{l}\text { Garis pantai; kawasan berpasir, } \\
\text { berbatu dan yang ditumbuhi } \\
\text { pokok; struktur lineamen/sesar/ } \\
\text { kekar; kawasan dataran atau } \\
\text { berbukit; fitur geomorfologi } \\
\text { seperti pentas hakisan dan } \\
\text { kakik laut }\end{array}$ & $\begin{array}{l}\text { Dron boleh mengambil gambar secara tegak ke bawah } \\
\text { dan juga ke arah sisi dan boleh terbang tinggi atau } \\
\text { rendah mengukit keperluan. Oleh itu, semua maklumat } \\
\text { yang diperoleh melalui imej satelit juga boleh diperoleh } \\
\text { dengan mengkaji gambar daripada dron, malah } \\
\text { maklumatnya lebih baik berbanding imej satelit. Pada } \\
\text { peringkat ini peta geomorfologi sudah boleh dibuat }\end{array}$ \\
\hline 5 & Kerja lapangan & $\begin{array}{l}\text { Maklumat litologi dan fasies; } \\
\text { struktur batuan (sedimen } \\
\text { atau canggaan); fosil; fitur } \\
\text { geomorfologi }\end{array}$ & $\begin{array}{l}\text { Taburan litologi/fasies batuan dengan mudah boleh } \\
\text { dimasukkan dalam peta yang dihasilkan daripada } \\
\text { gabungan imej satelit dan gambar dron. Peta geologi } \\
\text { yang lengkap dapat dibina pada peringkat ini }\end{array}$ \\
\hline 6 & $\begin{array}{l}\text { Analisis dan sintesis } \\
\text { data serta penilaian dan } \\
\text { penarafan tapak }\end{array}$ & $\begin{array}{l}\text { Peta geotapak; pembangunan } \\
\text { geotrail }\end{array}$ & $\begin{array}{l}\text { Fitur geologi dan geomorfologi yang bernilai tinggi } \\
\text { ditandakan di atas peta untuk dijadikan peta geotapak. } \\
\text { Setiap tapak yang penting ini dihubungkan melalui satu } \\
\text { laluan yang dipanggil geotrail. Apabila selesai mengikuti } \\
\text { keseluruhan geotrail ini, pengunjung akan memahami } \\
\text { sejarah pembentukan Pulau Ular }\end{array}$ \\
\hline
\end{tabular}




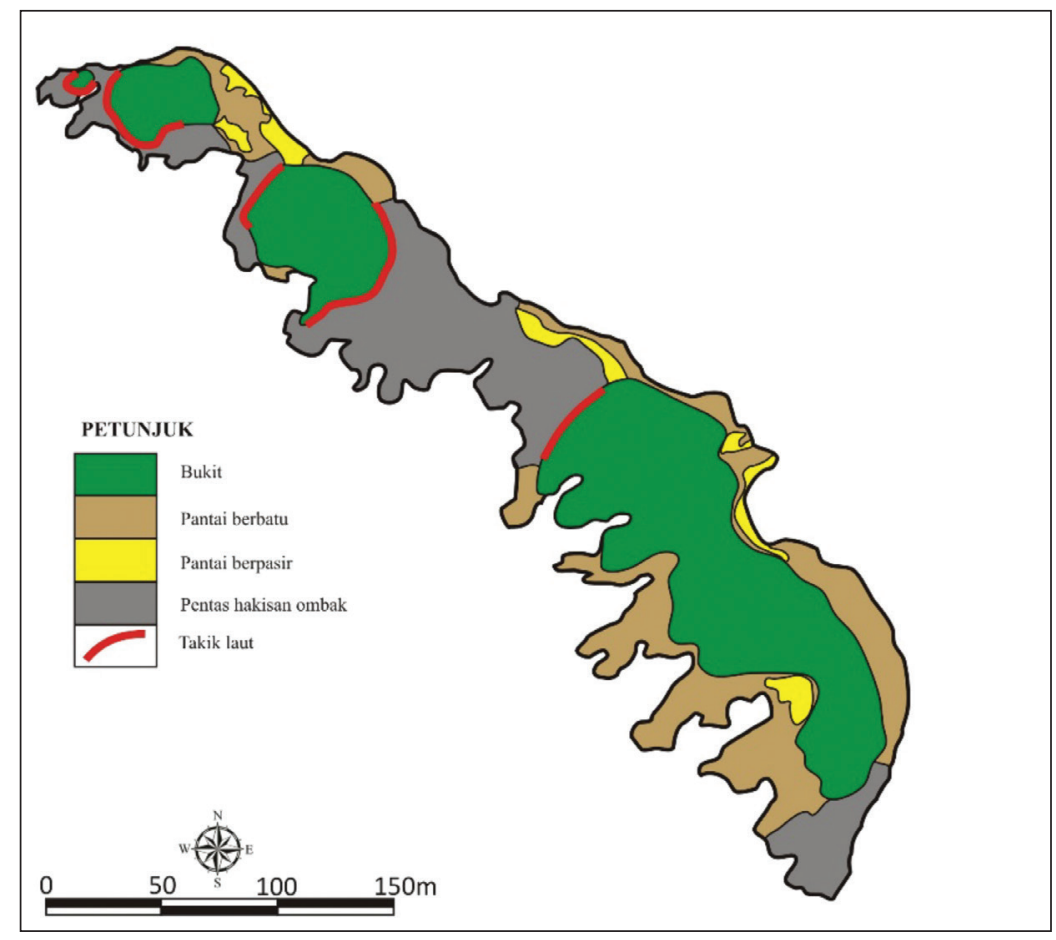

RAJAH 2. Peta geomorfologi Pulau Ular

Unit pertama terdiri daripada selanglapis nipis syal dengan lodak, dan juga pasir halus. Lapisan batu pasir dan lodak tidak berterusan, iaitu kadang-kadang kelihatan seperti lapisan yang putus-putus. Unit nendatan juga banyak terdapat dalam unit pertama ini terutamanya di bahagian bawah jujukan. Unit kedua terdiri daripada selang lapis nipis batu syal dengan lodak, tetapi berbeza dengan unit pertama kerana di sini terdapat banyak fosil surih. Fosil surih yang ditemui adalah dari jenis yang menjalar di atas permukaan, dan terdapat juga sedikit yang mengorek lapisan. Unit kedua ini tiada struktur nendatan berbanding dengan unit pertama. Unit ketiga dan yang paling atas dalam Ahli Ular terdiri daripada batu pasir halus hingga kasar, dan berlapisan tebal hingga masif. Unit batu pasir ini mempunyai lapisan silang.

Secara amnya, Ahli Ular merupakan satu jujukan batuan yang mempunyai jujukan mengkasar ke atas

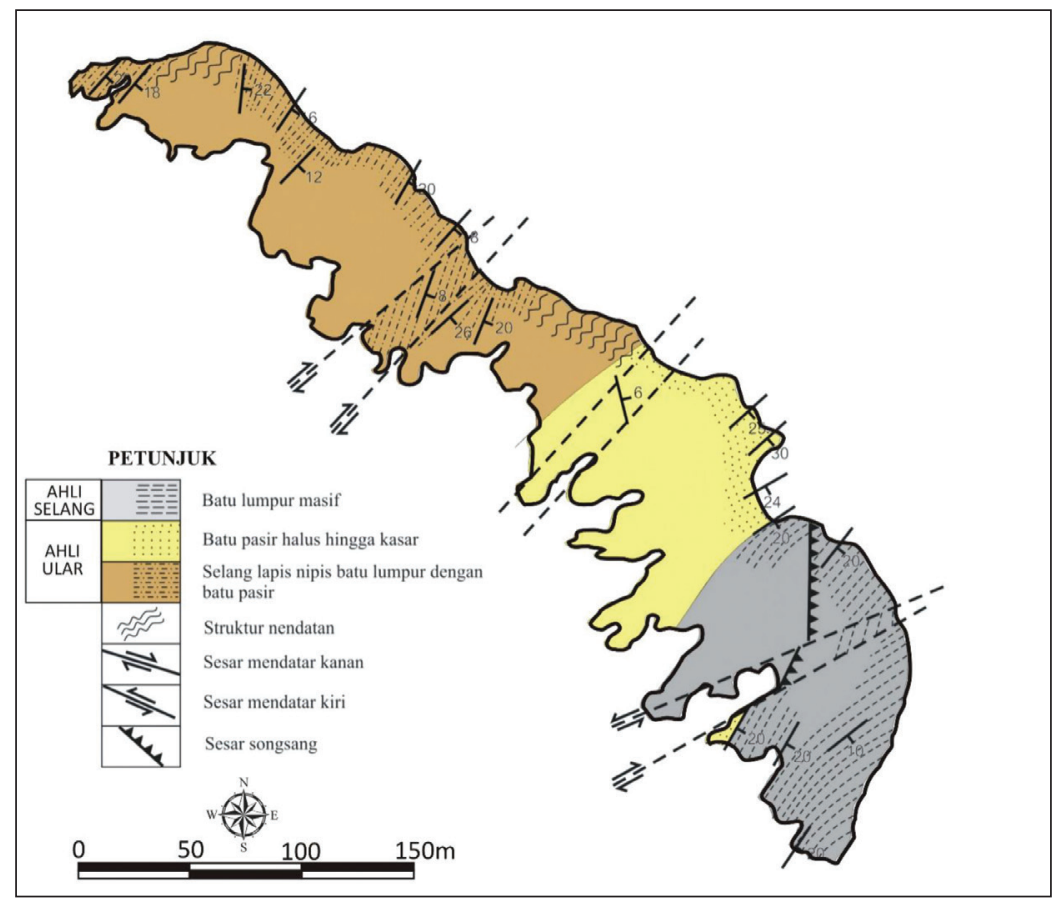

RAJAH 3. Peta geologi Pulau Ular 
(bermula daripada syal dan lodak halus hingga pasir berlapisan silang). Jujukan ini ditafsirkan jujukan regresi, iaitu lembangan pemendapan Ahli Ular dipenuhi oleh sedimen. Di atas Ahli Ular, tersingkap jujukan batuan syal hitam yang berpebel (Ahli Selang). Sempadan antara kedua-dua ahli ini sangat jelas, iaitu batu pasir masif/tebal Ahli Ular tiba-tiba diikuti oleh syal hitam Ahli Selang.

Ahli Selang Ahli Selang terdiri daripada syal hitam yang kebanyakannya berpebel. Pebel dalam syal hitam ini ada berbagai jenis, dan kebanyakannya berbentuk bersegi dan bersudut. Antara pebel yang ada ialah pebel batu pasir, kuarza, syal, batu kapur dan juga granit. Saiz pebel berbagai, daripada beberapa mm hingga beberapa $\mathrm{cm}$. Kebanyakan saiz pebel ialah 0.5 hingga $1 \mathrm{~cm}$. Pebel tertabur secara rawak. Terdapat beberapa lapisan batu pasir nipis di beberapa tempat setebal 1 hingga $3 \mathrm{~cm}$. Satu lagi yang penting yang terdapat dalam Ahli Selang ini ialah fosil surih. Terdapat dua jenis fosil surih, satunya yang menjalar atas satah perlapisan, dan satu lagi memotong atau mengorek lapisan. Jenis yang pertama lebih dominan. Saiz fosil surih ini daripada $0.5 \mathrm{~cm}$ hingga $1 \mathrm{~cm}$ lebar atau besar fosil, dan panjang lengkarannya mencapai 15 $\mathrm{cm}$. Jenis fosil surih yang ada ialah Palaeophycus, dan

JADUAL 2. Pencirian setiap tapak geologi dan landskap yang ada di Pulau Ular

\begin{tabular}{|c|c|c|}
\hline $\begin{array}{c}\text { Nombor } \\
\text { tapak }\end{array}$ & Fitur geologi utama & Pencirian \\
\hline 1 & $\begin{array}{l}\text { Turus laut \& struktur } \\
\text { nendatan } \\
\text { (Rajah } 5(\mathrm{~A}))\end{array}$ & $\begin{array}{l}\text { Di bahagian hujung utara pulau terdapat bentuk bumi berbentuk turus, hasil daripada proses } \\
\text { hakisan lautan. Batuan yang membentuk turus ini terdiri daripada batu lumpur yang mempunyai } \\
\text { struktur mendapan yang menjelaskan berlakunya gelungsuran sedimen semasa peringkat awal } \\
\text { pembentukan batuan di Pulau Ular }\end{array}$ \\
\hline 2 & $\begin{array}{l}\text { Batu lumpur, lodak \& } \\
\text { pasir halus biokacau } \\
\text { (Rajah } 5(B))\end{array}$ & $\begin{array}{l}\text { Unit selang lapis lumpur-lodak-pasir halus yang mempunyai struktur biokacau (bioturbation) } \\
\text { akan menjelaskan bahawa lautan tenang yang menjadi tempat pemendapan batuan ini mempunyai } \\
\text { banyak hidupan. Aktiviti hidupan ini menyebabkan laminasi yang terbentuk telah musnah sama } \\
\text { sekali }\end{array}$ \\
\hline 3 & $\begin{array}{l}\text { Pentas hakisan ombak } \\
\text { (Rajah 5(C)) }\end{array}$ & $\begin{array}{l}\text { Kawasan antara bukit terdiri daripada dataran rendah yang sangat landai, yang merupakan pentas } \\
\text { hakisan ombak. Dataran ini mempunyai ketinggian sekitar } 1 \text { meter di atas aras laut sekarang. Ini } \\
\text { mencadangkan aras laut dahulu lebih tinggi daripada aras laut sekarang }\end{array}$ \\
\hline 4 & $\begin{array}{l}\text { Takik laut kuno } \\
\text { (Rajah 5(D)) }\end{array}$ & $\begin{array}{l}\text { Di tepi bukit yang bersempadan dengan pentas hakisan ombak jelas terdapat satu lekuk di bahagian } \\
\text { kaki bukit, yang dikenali sebagai takik ombak. Takik ombak ini terhasil akibat hentaman dan } \\
\text { hakisan ombak. Beberapa takik lain yang berketinggian berbeza juga boleh diperhatikan. Takik } \\
\text { ini juga menjelaskan kedudukan aras laut pada suatu masa dahulu. Pembentukan pentas hakisan } \\
\text { ombak dan takik laut kuno ini dijangkakan berlaku pada zaman Tertier atau Holosen }\end{array}$ \\
\hline 5 & $\begin{array}{l}\text { Struktur sesar zaman } \\
\text { Tertier } \\
\text { (Rajah } 5(\mathrm{E}))\end{array}$ & $\begin{array}{l}\text { Retakan pada pentas hakisan ombak menunjukkan terdapat sedikit anjakan. Pentas hakisan ini } \\
\text { terbentuk pada zaman Holosen, dan ini bermakna satah sesar ini terbentuk kemudian, iaitu lebih } \\
\text { lewat. Ini adalah bukti terdapat sesar aktif pada zaman Holosen di Langkawi }\end{array}$ \\
\hline 6 & $\begin{array}{l}\text { Batu pasir tebal } \\
\text { (Rajah } 5(\mathrm{~F}))\end{array}$ & $\begin{array}{l}\text { Lapisan batu pasir tebal hingga massif, terdiri daripada batu pasir halus hingga sederhana kasar. } \\
\text { Secara umumnya, Formasi Singa dominan dengan batu lumpur, tetapi di sini terdapat juga batu } \\
\text { pasir. Daripada tapak } 1 \text { hingga ke tapak } 6 \text {, boleh diperhatikan terdapat jujukan mengkasar ke } \\
\text { atas, yang dikaitkan dengan pemendapan semasa regresi di sekitaran pesisir. Keseluruhan jujukan } \\
\text { ini adalah daripada Ahli Ular }\end{array}$ \\
\hline 7 & $\begin{array}{l}\text { Sempada stratigrafi } \\
\text { Ahli Ular-Ahli } \\
\text { Selang } \\
(\text { Rajah } 5(\mathrm{G}))\end{array}$ & $\begin{array}{l}\text { Formasi Singa di Pulau Ular dibahagikan kepada Ahli Ular dan juga Ahli Selang. Di tapak ini } \\
\text { boleh diperhatikan jujukan batuan berwarna kehitaman menindih secara selaras unit batuan } \\
\text { lumpur dan batu pasir yang warnanya lebih cerah. Ini merupakan sempadan antara dua ahli yang } \\
\text { ada dalam Formasi Singa. Perubahan Ahli Ular kepada Ahli Selang dikaitkan dengan perubahan } \\
\text { persekitaran pengendapan pada masa tersebut }\end{array}$ \\
\hline 8 & $\begin{array}{l}\text { Batu lumpur berpebel } \\
\& \text { fosil surih } \\
\text { (Rajah } 5(\mathrm{H}))\end{array}$ & $\begin{array}{l}\text { Dalam lapisan batu lumpur hitam boleh diperhatikan fosil surih yang terletak selari di atas satah } \\
\text { lapisan. Ini adalah surihan aktiviti hidupan pada masa pemendapan Ahli Selang sedang berlaku. } \\
\text { Di tapak ini juga terdapat pebel-pebel batuan berbagai jenis dan bentuk, kebanyakannya bersaiz } \\
\text { beberapa cm tertabur dalam lapisan batu lumpur. Batu lumpur berpebel ini dikaitkan dengan } \\
\text { endapan glasier di kawasan beriklim sejuk }\end{array}$ \\
\hline 9 & $\begin{array}{l}\text { Fosil karang \& batu } \\
\text { lumpur berpebel } \\
\text { (Rajah 5(I)) }\end{array}$ & $\begin{array}{l}\text { Di tapak ini masih boleh ditemui fosil surih dan juga pebel batuan dalam lapisan batu lumpur } \\
\text { hitam. Satu yang penting di sini ialah terdapatnya fosil karang dan bryzoa dalam batu lumpur }\end{array}$ \\
\hline 10 & $\begin{array}{l}\text { Konglomerat, batu } \\
\text { pasir \& struktur } \\
\text { palong } \\
(\text { Rajah } 5(\mathrm{~J}))\end{array}$ & $\begin{array}{l}\text { Di sini terdapat kekanta konglomerat (saiz granul) berselang lapis dengan batu pasir kasar. } \\
\text { Struktur palong serta lapisan silang jelas kelihatan. Jujukan ini merupakan sebahagian daripada } \\
\text { Ahli Ular yang terendap di sekitaran pesisir yang bertenaga tinggi. Sesar telah menganjakkan } \\
\text { jujukan berbutir kasar ini sehingga kelihatan berada dalam Ahli Selang yang berbutir halus }\end{array}$ \\
\hline
\end{tabular}


Thalassinoides. Selain itu terdapat juga fosil karang di bahagian atas jujukan.

Setelah data lapangan dikumpulkan dan ditanda di atas peta dasar, maka satu peta geologi pun terhasil (Rajah 3). Maklumat litologi, fasies serta litostratigrafi dimasukkan dalam peta berserta dengan kedudukan fitur geologi yang ditemui (sesar, fosil dan mendatan).

\section{ANALISIS GEOTAPAK}

Pada peringkat ini, maklumat daripada penderiaan jauh dan data lapangan digabungkan dan analisis dijalankan untuk mencari fitur geologi yang sangat penting yang menjadi bukti kepada proses geologi yang telah berlaku di Pulau Ular khasnya dan sejarah geologi Langkawi dan Malaysia amnya. Tapak yang telah dikenal pasti ini dicirikan dan dibuat penilaian serta penarafan, kemudian ditandakan di atas peta untuk menghasilan peta geotapak (Rajah 4). Untuk Pulau Ular, tapak penting ini ditanda di atas peta geomorfologi, berbanding di atas peta geologi kerana kebanyakan orang awam dan pelancong lebih mudah memahami geomorfologi berbanding geologi. Walau bagaimanapun, dalam penjelasan untuk setiap tapak yang ada, maklumat geologi perlu diberi dengan terperinci supaya pelancong boleh memahami sejarah geologi Pulau Ular.

\section{TAPAK PENTING DI PULAU ULAR}

Sebanyak 10 lokaliti atau tapak telah dikenal pasti di Pulau Ular, dengan setiap tapak yang dipilih mempunyai fitur geologi atau landskap yang penting kepada pemahaman sejarah pembentukan pulau ini, antaranya kepelbagaian jenis batuan, fosil, struktur sedimen, struktur tektonik dan struktur hakisan. Tapak ini diringkaskan dalam Jadual 2.

Kedudukan tapak ini ditunjukkan dalam peta geotapak Pulau Ular (Rajah 4). Kesemua tapak yang disenaraikan dalam Jadual 2 menggambarkan kekayaan kepelbagaian geologi yang ada di Pulau Ular (Rajah 5). Kepelbagaian geomorfologi ditunjukkan oleh tapak 1, 3 dan 4; kepelbagaian litologi di tapak 2, 6, 8 dan 10; kepelbagaian fosil di tapak 9; kepelbagaian struktur tektonik di tapak 5; dan tapak 7 penting daripada segi sempadan stratigrafi.

\section{KEPUTUSAN}

Pulau Ular merupakan salah satu geotapak penting di kepulauan Langkawi dengan semua sejarah pembentukan bumi Langkawi untuk zaman Perm boleh diperoleh atau dapat dibuktikan di pulau ini. Berdasarkan pemetaan ini didapati sepuluh tapak penting yang mewakili kepelbagaian geologi batuan Formasi Singa, kepelbagaian fosil surih untuk hidupan laut dalam, struktur primer semasa pembentukan batuan, struktur sekunder yang dihasilkan oleh pergerakan sesar dan kepelbagaian rupa bumi yang dihasilkan oleh hakisan ombak.

Peta geotapak yang dihasilkan digunakan pada peringkat penilaian dan penarafan warisan geologi berdasarkan kepentingan yang telah dicirikan. Berdasarkan aktiviti pemetaan geotapak ini turut dikenal pasti bahawa usaha memelihara dan seterusnya mencirikan sesebuah geotapak memerlukan kepakaran dalam bidang geosains.

Pemetaan tapak ini menggabungkan pelbagai peta yang membantu persempadanan tapak penting untuk

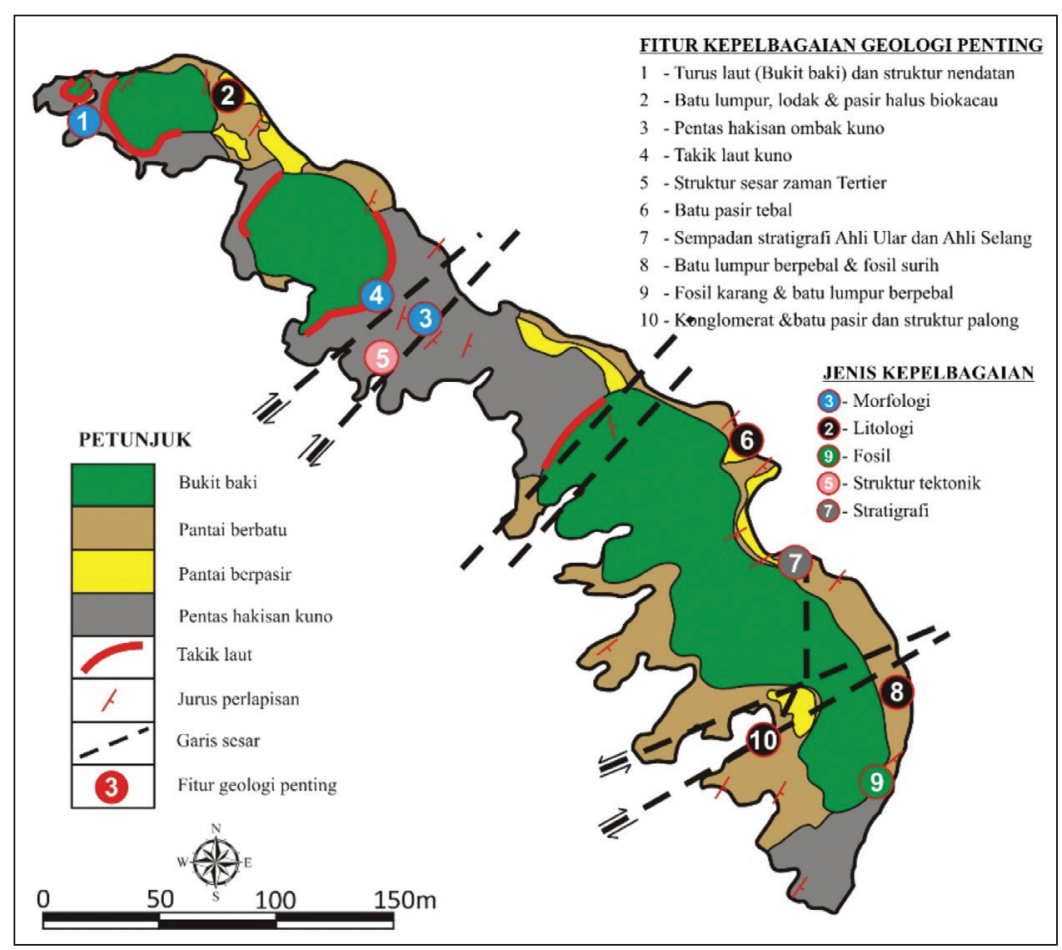

RAJAH 4. Peta geotapak Pulau Ular 


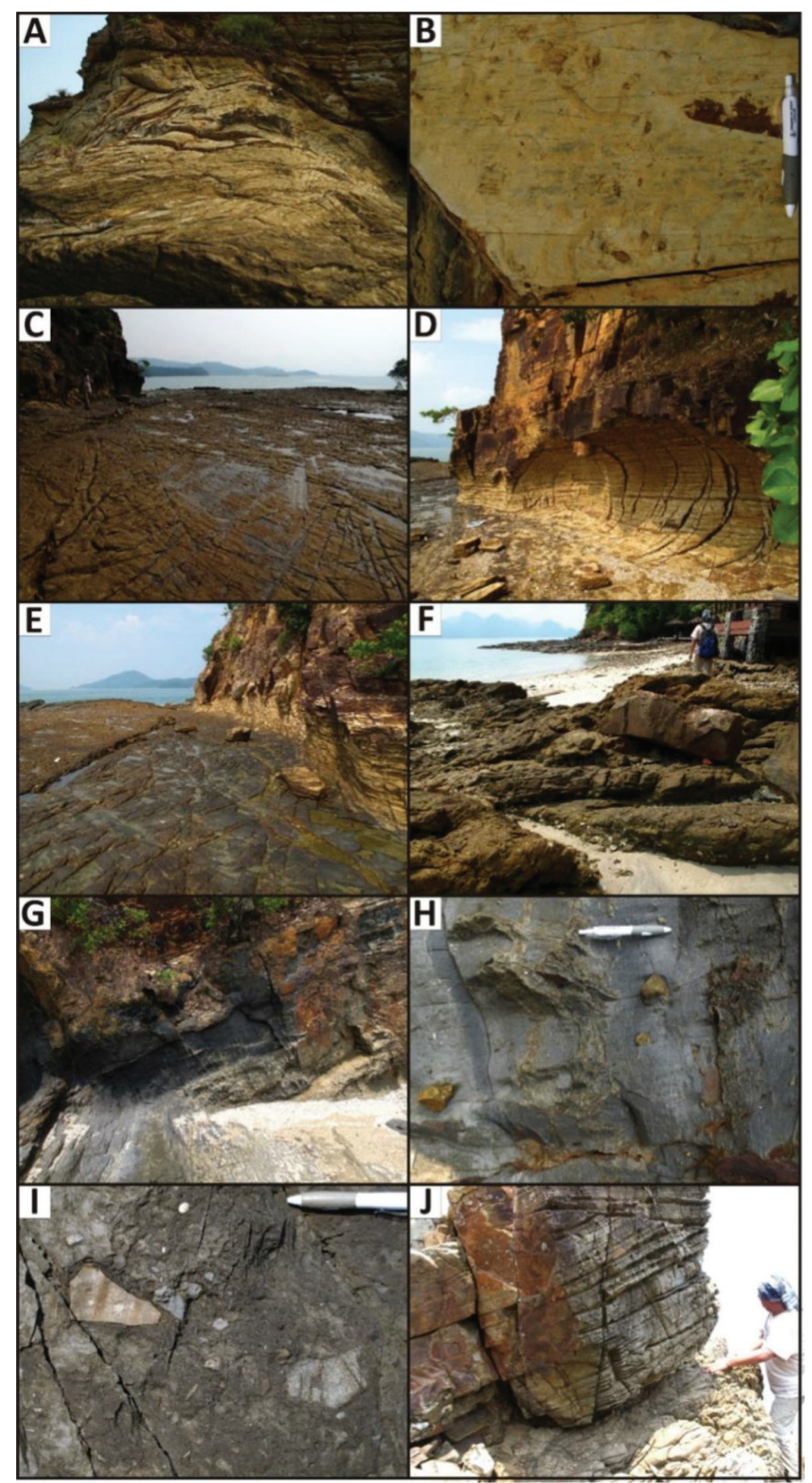

RAJAH 5. Fitur geologi dan landskap di setiap tapak. Penjelasan untuk setiap rajah boleh dirujuk dalam Jadual 2

tujuan pemuliharaan dan juga penyediaan buku panduan lapangan serta potensi geopelancongan untuk kawasan ini dan sekitarnya. Pengumpulan maklumat aspek kepelbagaian yang dipermudahkan menggunakan peta geotapak ini merupakan salah satu langkah penting dalam pencirian sumber warisan geologi. Peta ini perlu digabungkan dengan aspek pemuliharaan dan pembangunan lestari geopelancongan dan digunakan secara berkesan selaras dengan pelan perancangan tempatan dan Pelan Pelan Pengurusan Langkawi Geopark (Tanot Unjah et al. 2012).
PENGHARGAAN

Penyelidikan dan penerbitan ini telah dibiayai oleh projek penyelidikan Arus Perdana FRGS/2/2014/STWNO6/ UKM/01/1 dan juga peruntukan Pusat Penyelidikan Langkawi LIV-2015-03. Terima kasih diucapkan kepada Universiti Kebangsaan Malaysia kerana menyediakan kemudahan prasarana terutamanya peralatan makmal di Pusat Penyelidikan Langkawi, Kampus Tuanku Abdul Halim Mu'adzam Shah, Langkawi dan juga makmal di Fakulti Sains dan Teknologi, kampus Bangi. 


\section{RUJUKAN}

Ahmad Jantan. 1973. Stratigraphy of the Singa Formation (Upper Paleozoic) in the Southwestern part of Langkawi Island Group, West Malaysia. Tesis Sarjana Sains, Universiti Malaya (tidak diterbitkan).

Fuertes-Gutiérrez, I. \& Fernández-Martínez, E. 2012. Mapping geosites for geoheritage management: A methodological proposal for the Regional Park of Picos de Europa (León, Spain). Environ. Manag. 50: 789-806.

Gobbett, D.J. 1972. Geology of the Rebak Islands, Langkawi, West Malaysia. Geological Society of Malaysia Newsletter 37: 1-5.

Hamada, T. 1969. Late Palaeozoic brachiopods from red beds in the Malayan Peninsula. Dlm. Geology and Palaeontology of Southeast Asia 6, disunting oleh Kobayashi, T. \& Toriyama, R. Tokyo: The University of Tokyo Press. hlm. 251-264.

Hamada, T. 1968. Ambocoeliids from Red Beds in the Malaysan Peninsula. Dlm. Geology and Palaeontology of Southeast Asia, disunting oleh Kobayashi, T. \& Toriyama, R. Tokyo: The University of Tokyo Press. hlm. 13-25.

Jones, C.R. 1981. Geology of Perlis, North Kedah and the Langkawi Islands. Geological Survey of Malaysia District Memoir. p. 17.

Kobayashi, T. \& Hamada, T. 1973. Cyrtosymbolids (Tribolita) from the Langgun Red Beds in Northwest Malaya, Malaysia. Geology and Palaeontology of Southeast Asia 12. Tokyo. The University of Tokyo Press. hlm. 1-26.

Koopmans, B.N. 1965. Structural evidence for a Paleozoic orogeny in north-west Malaya. Geological Magazine 102(6): 501-520.

Leonova, T.B., Mohd. Shafeea Leman \& Shi, G.R. 1999. Discovery of an Early Permian (Late Sakmarian) ammonoid form Langkawi Island, Malaysia. Alcheringa 23: 277-281.

Mat Niza Abdul Rahman, Hamid Ariffin, Mohamad Hussein Jamaluddin \& Imsamut, S. 2014. Lithostratigraphic correlation of the Rebak/Khuan Klang Formation along the Malaysia-Thailand border area. Proceeding National Geoscience Conference 2014. hlm. 199-201.

Mohamad Hanif Kamal Roslan, Che Aziz Ali \& Kamal Roslan Mohamed. 2018. Pengelasan litostratigrafi baru untuk Formasi Singa di Langkawi, Kedah, Malaysia. Sains Malaysiana 47(10): 2251-2258.

Mohamad Hanif Kamal Roslan, Che Aziz Ali, Kamal Roslan Mohamed \& Mohd. Shafeea Leman. 2017. Taburan fosil dan penilaian semula usia Formasi Singa di Langkawi, Kedah Darul Aman, Malaysia. Sains Malaysiana 46(12): 2359-2365.

Mohamad Hanif Kamal Roslan, Che Aziz Ali \& Kamal Roslan Mohamed. 2016. Fasies dan sekitaran sedimen Formasi Singa di Langkawi, Malaysia. Sains Malaysiana 45(12): 1897-1904.

Mohd. Shafeea Leman. 2003. An Early Permian (Early Sakmarian) brachiopod fauna from the Sungai Itau Quarry and its relationship to other Early Permian brachiopod horizon in Langkawi, Malaysia. Bulletin of the Geological Society of Malaysia 46: 155-160.

Mohd. Shafeea Leman. 1997a. Batuan formasi singa di Pulau Langkawi. Dlm. Warisan Geologi Malaysia Pemuliharaan untuk Ekopelancongan, disunting oleh Ibrahim Komoo, Mohd. Shafeea Leman, Kadderi Md Desa \& Ibrahim Abdullah. Bangi: Institut Alam dan Pembangunan (LESTARI). hlm. 185-207.

Mohd. Shafeea Leman. 1997b. The age and paleobiogeography of brachiopod fauna discovered in pebbly mudstone at Kilim, Langkawi. Bulletin of the Geological Society of Malaysia 40: 233-240.
Mohd. Shafeea Leman. 1996. The occurrences of brachiopods from pebbly mudstone near Kilim, Langkawi: Their age, paleobiogeography and paleoclimatic implication. Warta Geologi 22(2): 100-102.

Ovreiu, A.B., Comănescu, L., Bărsoianu, I.A. \& Nedelea, A. 2019. Evaluating geomorphosites and the geomorphological hazards that impact them: Case study-Cozia Massif (Southern Carpathians, Romania) Geoheritage (in review). hlm. 1-21. https://doi.org/10.1007/s12371-019-00352-7.

Prosser, C., Murphy, M. \& Larwoord, J. 2006. Geological Conservation: A Guide to Good Practice. Peterborough: English Nature.

Regolini-Bissig, G. 2010. Mapping geoheritage for interpretive purpose: Definition and interdisciplinary approach. Dlm. Mapping Geoheritage, disunting oleh Regolini-Bissig, G. \& Reynard, E. Volume 35. Lausanne: Institut de Geographie, Geovisions.hlm. 1-13.http://www.unil.ch/igd/files/live/sites/ igd/files/shared/Geovisions/Geovisions35/Geovisions35_ IGUL_1_Regolini.pdf.

Regolini-Bissig, G. \& Reynard, E. 2010. Mapping Geoheritage, Geovisions, 35, Lausanne, Institut de Geographie. http://igd. unil.ch/www/ geovisions/35/ Geovisions35.pdf.

Sarkar, S.S. 1972. On the Posidonia from Rebak Islands Langkawi, West Malaysia. Geological Society of Malaysia Newsletter 37: 5-9.

Shi, G.R., Mohd. Shafeea Leman \& Tan, B.K. 1997. Early Permian brachiopods from the Singa Formation of Langkawi Island, northwestern Peninsular Malaysia: Biostratigraphical and biogeographical implications. Warta Geologi (Newsletter of the Geological Society of Malaysia) 23(4): 62-72.

Silva, J.P., Rodrigues, C. \& Pereira D.I. 2014. Mapping and analysis of geodiversity indices in the Xingu River Basin, Amazonia, Brazil. Geoheritage 7(4): 337-350.

Stauffer, P.H. \& Lee, C.P. 1986. Late Paleozoic glacial marine facies in Southeast Asia and its implications. Bulletin of the Geological Society of Malaysia 20: 363-397.

Stauffer, P.H. \& Manjit, N. 1981. Late paleozoic tilloid of Malaya, Thailand and Burma. Dlm. Earth's Pre-Pleistocene Glacial Records, disunting oleh Hanbrey, M.J. \& Harland, W.B. Cambridge: Cambridge University. hlm. 331-337.

Tanot Unjah, Che Aziz Ali, Mohd. Shafeea Leman \& Jasni Yaakob. 2012. Pemuliharaan warisan geologi. Dlm. Pelan pengurusan Langkawi Geopark (PPLG), disunting oleh Halimaton Saadiah Hashim, Rahimah Abd Aziz, Sarah Aziz, Ong Puay Liu \& Chan Kim, Ling @ Geraldine (Pnyt). Bangi: LESTARI, Universiti Kebangsaan Malaysia. hlm. 2012-2030.

Wang, G., Ye, W. \& Lv, Y. 2019. Loess geoheritage and geohazard protective measures at luochuan loess national geopark in NW China. Geoheritage (in review). hlm. 1-12 https://doi.org/10.1007/s12371-019-00354-5.

Yancey, T.E. 1972. Devonian fossils from Pulau Rebak Besar, Langkawi Island, West Malaysia. Geological Society of Malaysia Newsletter 37: 10-12.

Kamal Roslan Mohamed*, Tanot Unjah, Che Aziz Ali \& Mohamad Hanif Kamal Roslan

Pusat Penyelidikan Langkawi

Institut Alam Sekitar dan Pembangunan (LESTARI)

Universiti Kebangsan Malaysia

43600 UKM Bangi, Selangor Darul Ehsan

Malaysia 
Kamal Roslan Mohamed* \& Mohamad Hanif Kamal Roslan Pusat Pengajian Sains Bumi dan Alam Sekitar

Fakulti Sains dan Teknologi

Universiti Kebangsaan Malaysia

43600 UKM Bangi, Selangor Darul Ehsan

Malaysia
*Pengarang untuk surat-menyurat; email: kamal@ukm.edu.my

Diserahkan: 11 April 2019

Diterima: 15 Ogos 2019 